Provided for non-commercial research and education use. Not for reproduction, distribution or commercial use.

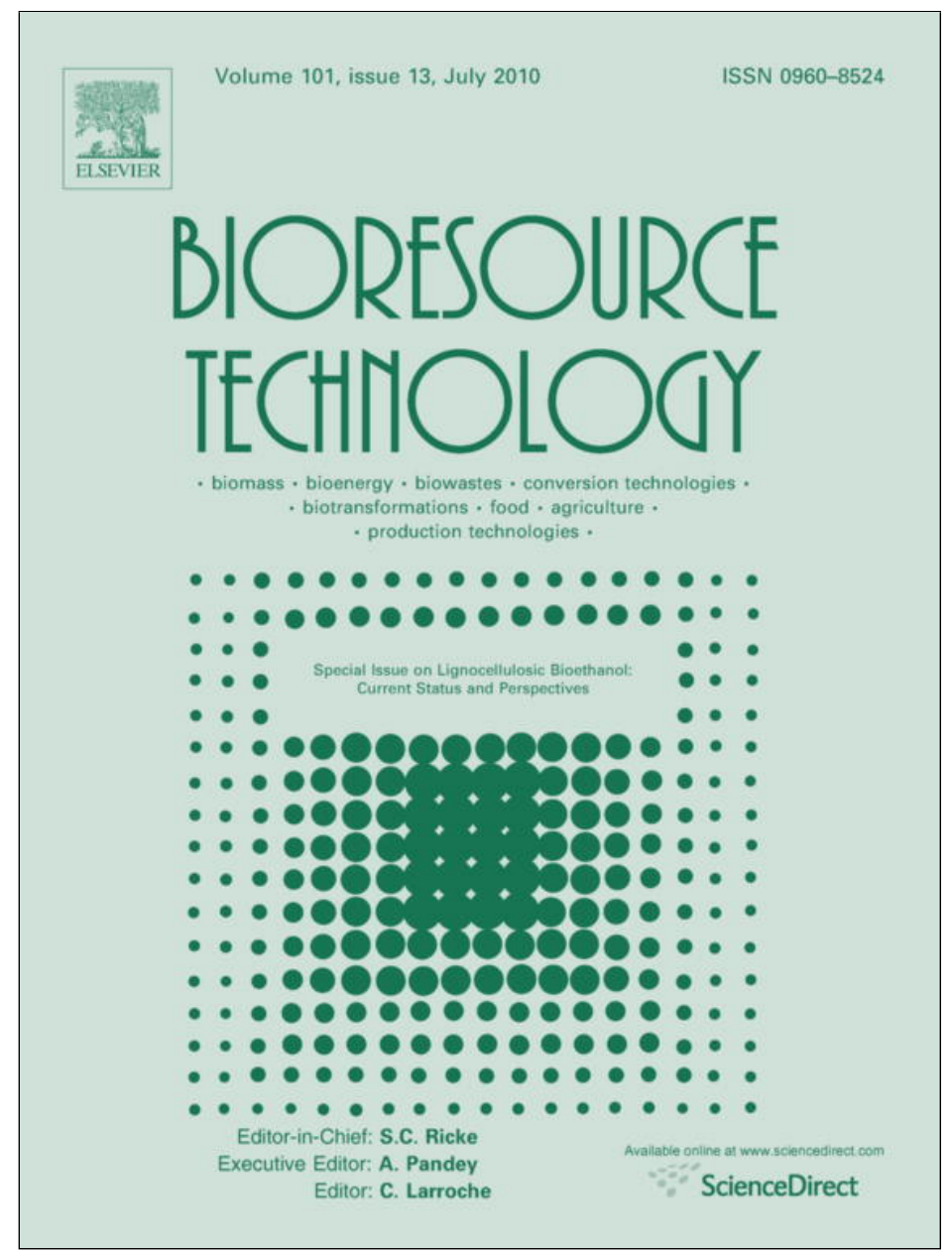

This article appeared in a journal published by Elsevier. The attached copy is furnished to the author for internal non-commercial research and education use, including for instruction at the authors institution and sharing with colleagues.

Other uses, including reproduction and distribution, or selling or licensing copies, or posting to personal, institutional or third party websites are prohibited.

In most cases authors are permitted to post their version of the article (e.g. in Word or Tex form) to their personal website or institutional repository. Authors requiring further information regarding Elsevier's archiving and manuscript policies are encouraged to visit:

http://www.elsevier.com/copyright 
Review

\title{
Techno-economic analysis of lignocellulosic ethanol: A review
}

\author{
Edgard Gnansounou *, Arnaud Dauriat \\ Swiss Federal Institute of Technology, Bioenergy and Energy Planning Research Group (EPFL), ENAC INTER GR-GN, 1015 Lausanne, Switzerland
}

\section{A R T I C L E I N F O}

\section{Article history:}

Received 16 October 2009

Received in revised form 30 January 2010

Accepted 3 February 2010

Available online 4 March 2010

\section{Keywords:}

Techno-economic

Value Engineering

Target Costing

Lignocellulosic ethanol

Value-based approach

\begin{abstract}
A B S T R A C T
Lignocellulosic ethanol is expected to be commercialised during the next decade as renewable energy for transport. Competiveness with first generation bioethanol and with gasoline is commonly considered in techno-economic analyses for commercial stage. Several existing reviews conclude about the high spread of current and projected production costs of lignocellulosic ethanol due to the significant differences in assumptions concerning the following factors: composition and cost of feedstock, process design, conversion efficiency, valorisation of co-products, and energy conservation. Focusing on the studies in the United States of America and in Europe, the present review investigates the different natures of the techno-economic evaluations during the development process of the supply chain i.e., standard costing with respect to Value Engineering, and Target Costing based on the projected market price. The paper highlights the significant contribution of feedstock to the lignocellulosic ethanol production cost and the need to consider competition between different uses for resources. It is recommended the use of a value-based approach that considers sustainability characteristics and potential competition for resources complementarily to Target Costing and Value Engineering.
\end{abstract}

(c) 2010 Elsevier Ltd. All rights reserved.

\section{Introduction}

Ethanol produced from lignocellulosic feedstock is expected to become mature in the pace of five to ten years and partly replace first generation ethanol. Bioethanol demand is increasing rapidly in industrialised countries, particularly in the United States of America (US) and in European countries, as a consequence of mandatory targets. Research works are going on in several countries with the aim of improving the efficiency and economic performance of various pathways. The importance of lignocellulosic ethanol stems from the possibility to use assumed inexpensive feedstock, avoid direct and indirect competition with human food and animal feed and reduce the environmental risks i.e. soil degradation, and water and air pollution which are associated to first generation biofuels.

The necessity to monitor the research works with the aim of concentrating the efforts on those steps that are more influential requires designing the process at the suitable level of detail and modelling the production cost using sets of relevant and consistent assumptions. Compared to techno-economic analysis of common products, lignocellulosic ethanol shows such distinguished characteristics as: significant variety of pathways, especially the possibility to use a large range of feedstock, high uncertainty about the economic drivers, large number of stakeholders involved in the pathways and uncertainties related to their interactions.

\footnotetext{
* Corresponding author. Tel.: +41 216930627; fax: +41216932863.

E-mail address: edgard.gnansounou@epfl.ch (E. Gnansounou).
}

Published works on lignocellulosic ethanol often simplify this complexity by focusing on limited pathways, a narrow range of feedstock, few choices of economic factors and implicit assumptions with regards to the behaviour of the stakeholders. These assumptions change significantly from one study to the other, thereby making it intractable to compare different techno-economic evaluations. Existing reviews such as Galbe et al. (2007) highlight the variability of estimated ethanol production costs and find that the key drivers of those differences are feedstock cost and plant capacity.

During the last three decades, the amount of works on technoeconomic analyses of lignocellulosic ethanol has increased significantly with notable contributions of RD\&D in the US and to a lesser extent in Europe. This paper reviews these works focusing on the cases of the US and Europe. The convergence and differences between the published results are pointed out. Finally methodological issues are discussed particularly with regards to how to tackle the value chains of biomass when performing a techno-economic evaluation.

\section{State-of-the-art}

\subsection{The US cases}

As long as the techno-economic evaluation of lignocellulosic ethanol is concerned, the first detailed technical reports found in the literature concerning the US cases dates back to the mid-80's. 
Table 1

Early design cases of an acid hydrolysis-based ethanol plant (Badger Engineers, Inc., 1987).

\begin{tabular}{|c|c|c|c|c|c|}
\hline Design & Unit & Base case & Alternative case & Small-scale plant (I) & Small-scale plant (II) \\
\hline Production capacity & MM gal/yr & 25 & 25 & 5 & 5 \\
\hline No. of hydrolysis stages & - & 1 & 2 & 1 & 1 \\
\hline Wood feed rate & Dry $t / h$ & 73.8 & 66.0 & 14.8 & 14.8 \\
\hline \multicolumn{6}{|l|}{ By-products } \\
\hline Furfural & MM lb/yr & 130.2 & 93.1 & 26.0 & 26.0 \\
\hline Excess electricity & MW & 22 & - & 4.4 & - \\
\hline Outside utilities required & - & No & No & No & Yes (4.1 MW) \\
\hline
\end{tabular}

Especially in 1987, the US National Renewable Energy Laboratory (NREL) receives several technical reports delivered by subcontractors. Badger Engineers, Inc. (1987) study an acid hydrolysis-based ethanol plant using mixed hardwood chips as feedstock. Four design cases are analysed (Table 1). The differences between them are related to the size of the plant, the type of hydrolysis and the mode of electricity supply.

The main co-products in all the analysed cases are ethanol and furfural. The process description is based on eight unit areas i.e. feedstock handling, acid hydrolysis, fermentation, ethanol purification, furfural recovery, offsite tankage, waste treatment and utilities. The economic evaluation is performed using internal rate of return (IRR). In each case, the selling price of ethanol (after tax) required to reach a $15 \%$ IRR is estimated and results in a range of values from US\$1.23/gal (US\$0.32/l) for the base case (design case I) to US\$1.63/gal (US\$0.43/1) for the design case IV. The currency is for 1984.

Stone \& Webster Engineering Corp. (1987), another subcontractor, studies the economic feasibility of an enzyme-based ethanol plant of 15 million gallons of ethanol per year using wood from cultivated eucalyptus tree farms. The plant is supposed to be located near Hilo, on the island of Hawaii. The description of the process includes feedstock handling, pre-treatment by sulphuric acid impregnation and steam explosion, enzyme production, enzymatic hydrolysis, evaporation system to concentrate the glucose at the required level, fermentation, distillation and anaerobic digestion. In the base case, only hexoses are fermented. The pentose fraction of the wood is utilized to produce biogas which is then burned with the lignin fraction to produce the steam required by the process. The economic evaluation is based on constant US\$ of 1984 and 15\% IRR and results in a required ethanol selling price of US\$3.5/gal (US\$0.92/1). The base case assumes $100 \%$ equity. The sensitivity analysis with $75 \%$ equity and $25 \%$ debt at a real interest of $8 \%$ reduces the required selling price to US\$3.04/gal (US\$0.80/1).

A report on economic feasibility of an enzymatic hydrolysisbased ethanol is also released by Chem Systems, Inc. (1987). The size of the plant is 25 million gallons ethanol per year while the feedstock is supposed to be $80 \%$ hardwood (incl. $57 \%$ from Aspen forests) and $20 \%$ maples. The process is a separate hydrolysis and fermentation (SHF) with on-site enzyme production, carbon dioxide recovery and furfural production. The pre-treatment is dilute acid pre-hydrolysis. As for the case of Stone \& Webster Engineering Corp., the sugar solution obtained after the saccharification step is concentrated using a multi-effect evaporator. The economic feasibility analysis is performed based on IRR and an ethanol selling price of US\$2.06/gal (US\$0.54/1) is found with the IRR set to $10 \%$.

In addition to these feasibility studies, the techno-economic evaluation of lignocellulosic ethanol owes much to two studies by NREL in association with other US Research Institutes and Universities i.e. Wooley et al. (1999a) and Aden et al. (2002). Both studies are based on a detailed process design, mass and energy balance using ASPEN model and process economics evaluation. The former studies the simultaneous saccharification and co-fermentation (SSCF) of yellow poplar wood. The size of the plant is
52.2 million gallons (198 million litres) of ethanol per year. The pre-treatment is with dilute acid and the enzyme is produced on-site. The description of the process involves nine areas including SSCF, ethanol storage, cogeneration plant and other utilities. The economic performance is estimated also based on $10 \%$ IRR. Five cases are evaluated: two cases represent the current state of technology and the near-term best of industry; and three futuristic scenarios account for technology progress with ex ante snapshots of years 2005, 2010 and 2015. The economic performances of these cases are respectively, US\$1.44/gal ethanol, US $\$ 1.16$, US $\$ 0.94$, US\$0.82 and US\$0.76 (US\$ of 1997). In the case of 2015, the authors assume a $20 \%$ increase of carbohydrates due to biomass biotechnology improvements.

The second study (Aden et al., 2002) uses the same framework with the following main differences: (1) the feedstock is corn stover; the size of the plant is 69.3 million gallons ethanol per year; the on-site production of enzyme is removed and replaced by purchased enzymes. The levelised production cost based on $10 \%$ discount rate is US\$1.07/gal ethanol (US\$ of 2000). Updates of the technology model are provided in Aden (2008), Humbird and Aden (2009), and Aden and Foust (2009).

From 2002, the context of the techno-economic evaluation of lignocellulosic ethanol has changed with the launch of the Biomass Program of the US Department of Energy (DOE). Since 2007, the design of this programme has acquired a clear strategic goal with the aim of the public authorities to reduce the use of gasoline by $20 \%$ by 2017 and produce $35 \times 10^{9} 1$ of renewable and alternative fuels in 2017. Concerning the RD\&D in lignocellulosic bioethanol, a "multi-year program plan" (MYPP) is released and updated every two years, including so far 2005 (US DOE, 2005), 2007 (US DOE, 2007 ) and 2009 (US DOE, 2009). Two pathways are being studied, i.e. thermochemical and biochemical.

In the framework of the "biomass program", Phillips et al. (2007) release a technical report on thermochemical ethanol with the goal to achieve economic competitiveness of lignocellulosic ethanol with starch-based ethanol by 2012 . The feedstock is hybrid poplar wood chips. The process comprises seven main areas including feedstock handling and drying, gasification, gas cleanup and conditioning, alcohol synthesis and alcohol separation. The economic evaluation is based on levelised production cost also termed minimum ethanol selling price (MESP). Given a MESP of US\$1.07/gal ethanol, the design case is such as to meet that target with a discount rate of $10 \%$.

This approach is systematised in the MYPP (US DOE, 2005, 2007, 2009), where a global ethanol programme cost target (EPCT) is fixed along with compatible cost targets for the different areas of the process. Furthermore, the EPCT changes from one MYPP to the other in order to reflect currency value, escalation factors and the projected price of gasoline for the targeted year (Table 2).

As an example, the estimation of the EPCT in 2012 for the biochemical ethanol is based on the reference scenario by the Energy Information Administration (EIA, 2009) which forecasts the wholesale price of gasoline in 2012 at US\$2.62/gal gasoline (US\$ of 2007). Assuming a conversion factor of 0.67 gallon gasoline per gallon 
Table 2

Ethanol production cost breakdown according to US MYPPs: 2012 projections.

\begin{tabular}{|c|c|c|c|c|}
\hline & & MYPP 2005 & MYPP 2007 & MYPP 2009 \\
\hline Currency (reference year) & & US\$ of 2002 & US\$ of 2007 & US\$ of 2007 \\
\hline Feedstock (total) & US\$/dry ton & 35.00 & 45.90 & 50.90 \\
\hline Ethanol yield & gal/dry ton & 89.80 & 89.80 & 89.90 \\
\hline \multicolumn{5}{|l|}{ Supply chain areas } \\
\hline Feedstock (total) & US\$/gal & 0.39 & 0.51 & 0.57 \\
\hline Pre-hydrolysis/treatment & US\$/gal & 0.21 & 0.25 & 0.26 \\
\hline Enzymes & US\$/gal & 0.10 & 0.10 & 0.12 \\
\hline Saccharification and fermentation & US\$/gal & 0.09 & 0.10 & 0.12 \\
\hline Distillation and solids recovery & US\$/gal & 0.13 & 0.15 & 0.16 \\
\hline Balance of plant & US\$/gal & 0.17 & 0.22 & 0.26 \\
\hline Ethanol production (total) & US\$/gal & 1.08 & 1.33 & 1.49 \\
\hline
\end{tabular}

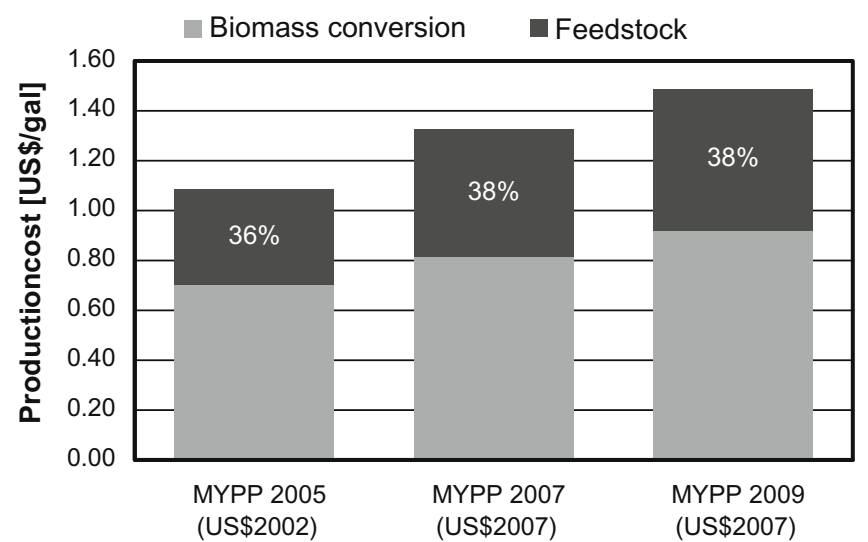

Fig. 1. Ethanol production cost breakdown according to US MYPPs: 2012 projections.

ethanol, the EPCT is set at US\$1.76/gal ethanol (US\$ of 2007). However, the Ethanol Cost Projection of the $n$th ethanol plant is at US\$1.49/gal ethanol (US\$ of 2007). The contribution made by feedstock production to the ethanol production cost increases from one MYPP to the other due to progress in understanding and estimating the feedstock production and logistics (Fig. 1).

\subsection{Other techno-economic evaluation cases}

Besides the techno-economic evaluations undertaken in the US, significant contributions are brought by European Research institutions mainly in Sweden, the Netherlands and Denmark. Galbe et al. (2007) present a review of the process economics of lignocellulosic ethanol published since 1996. They compare the production costs estimation of lignocellulosic ethanol of 15 studies undertaken in the US and in Europe and point out the high variability of the results. However, that comparison is somewhat tricky as the year of US\$ currency is not given by the authors. They point out the ethanol yield and the energy demand of the process as key influencing factors of the ethanol production cost for given feedstock and process configuration. Water insoluble solids (WIS) concentration and recirculation of process streams are investigated as options to reduce the energy demand and increasing the amount of coproducts.

Sassners et al. (2008) compare the techno-economic performances of conversion of lignocellulosics-to-ethanol based on three different feedstocks i.e. a softwood (spruce), a hardwood (salix) and an agricultural residue (corn stover). The process consists of $\mathrm{SO}_{2}$-catalysed steam explosion pre-treatment and simultaneous saccharification and fermentation (SSF). The feedstocks show sig- nificant differences between hexose and pentose ratios, i.e. 7.4 for spruce, 2.9 for salix and 1.6 for corn stover, based on weights' percentage of dry matters. However, for the percentage of $\mathrm{C} 5$ and C6 as a whole, corn stover is the first (68\%) followed by spruce $(67.5 \%)$ and salix (64.5\%). The process capacity of the ethanol plant is supposed to be 200,000 dry tons of biomass per year. The process parameters are adjusted to experimental data and adapted to each feedstock. Enzymes are assumed to be purchased while the yeasts are produced on-site. As an example, the temperature of steam pre-treatment is 195,190 and $205^{\circ} \mathrm{C}$ and the yeast concentration is $3.0,1.8$ and $2.5 \mathrm{~g} / \mathrm{l}$, respectively for salix, corn stover and spruce.

Three base cases are evaluated, one for each feedstock where conversion factors for steam pre-treatment and SSF are adapted from experimental and analytical research works at Lund University, Sweden. In the base cases, it is assumed that only the hexoses (glucan, galactan and mannan) are converted to ethanol. Material and energy balances are evaluated using Aspen Plus. The overall ethanol yields - taking into account sugar consumption for yeast production and ethanol losses within the process - are estimated to 239,215 and 2921 per dry metric ton for salix, corn stover and spruce, respectively. Note that the corresponding ethanol yields from hexoses are respectively, 245, 302 and 4261 per dry metric ton. Thus the estimated yields correspond to $69.3 \%, 71.2 \%$ and $68.5 \%$ of the potential yields for salix, corn stover and spruce, respectively. The lower value for spruce can be explained by the more severe pre-treatment conditions which result in more degradation of sugars and higher level of inhibitors. Alternative cases where both hexoses and pentoses are converted to ethanol are evaluated. They result in overall yield of 314, 306 and 3151 per dry metric ton for salix, corn stover and spruce respectively, these are $67.4 \%, 62.1 \%, 64.9 \%$ of the overall potential yield from hexoses and pentoses. Thus, compared to the base cases, the absolute yield (litres ethanol/dry metric ton of feedstock) increases with the conversion of pentoses into ethanol; however, the relative yields i.e. (simulated yield with regard to assumed process condition)/(theoretical yield) decrease. These results suggest the need of a trade-off between, on one side severe pre-treatment conditions which are favourable to a high digestibility of cellulose by enzymes but enhance the level of inhibitors and on the other side milder conditions that reduce the risk of hemicellulose sugars degradation and formation of inhibitors but decrease the digestibility of cellulose.

The authors define energy efficiency as the ratio between energy output (ethanol + solid fuel) and energy input (raw materials + electric power requirement). The raw materials, solid fuel (pellets) and ethanol are estimated using the higher heating value (HHV) and the efficiency for electricity generation is estimated to $30 \%$. For the base cases, the authors find the following energy efficiencies for ethanol output only: $25 \%$ (salix), $25 \%$ (corn stover) and $31 \%$ (spruce). These figures increase in case of the alternative cases 
and obviously when the outputs also consider solid fuel co-products. In the latter case, the energy efficiency is in the range of $52-53 \%$ for salix, $55 \%$ for corn stover and $56 \%$ for spruce.

The economic evaluation consists in estimating annual production cost including annualised capital cost using 7\% interest rate and 15 years depreciation period, and annual operation costs. The costs are expressed in US\$. The authors do not indicate the year of the currency. For the base cases the annual production costs (US\$) significantly vary, i.e. US\$0.69/1 ethanol (spruce), 0.86 (corn stover) and 0.87 (salix). For alternative cases, the costs become 0.66 (spruce), 0.67 (corn stover) and 0.72 (salix).

Wingren et al. (2008) perform a techno-economic evaluation of a SSF-based softwood-to-ethanol, with the objective to compare the impact of various downstream configurations, i.e. after the SSF, on the ethanol production cost. The base case consists in conversion of wood chips of spruce into ethanol. The water content of the feedstock is $50 \%$ and the composition on a dry weight basis is as follows: $45.0 \%$ glucan, $12.6 \%$ mannan, $2.6 \%$ galactan, $7.1 \%$ pentosans, $28.1 \%$ lignin and $4.6 \%$ acetyl groups, extractives and ash. The conversion process is the same as in Sassners et al. (2008). The downstream process consists in distillation-rectification and evaporation. The unfiltered mash including ethanol, lignin, yeast and water streaming from the SSF is pre-heated and distributed between the two distillation columns. The distillate is then sent to the rectifier while the stillage is processed in centrifuges for liquid-solid separation. The liquid is concentrated through an evaporator. The resulted syrup is blended to the stream with solid compounds and sent for drying. Part of the $85 \%$ dry matter resulting material is burned in the boiler to generate the primary process steam while the remainder is pelletized.

In the base case, the evaporator is composed of five effects. The alternative configurations analysed by the authors include the following options: (1) increase the number of effects in the evaporator; (2) reduce the number of strippers from two to one and integrate it with the evaporator; (3) use a mechanical vapour recompression (MVR) in order to increase the temperature of the latent heat leaving the last effect and use it to replace a significant part of the primary steam; the MVR requires however supplementary electrical energy; (4) finally, methanize the stillage and use the biogas to fuel the steam boiler while the produced sludge is burned in an incinerator. The economic evaluation uses the same approach as in Sassners et al. (2008). The interest rate, however, is $6 \%$. The production cost in (US\$/1) varies between 0.546 for the MVR option to 0.591 for the base case. The case of anaerobic digestion results in 0.549 (US\$/l) production cost. That is close to the least cost of 0.546 US\$/1. The currency is supposed to be nominal US\$.

In the REFUEL project (2006-2008) funded by the European Commission under the Intelligent Energy Europe programme, seven EU institutes have analysed the prospects for biofuels in terms of resource potential, costs and impacts of different biofuels, including lignocellulosic ethanol. Although the project is rather focused on the cost and availability of resources within the European Union, the production cost of biofuels is taken into account. The data for bioethanol production from cellulosic materials based on enzymatic hydrolysis pathway are obtained from the Energy Research Centre of the Netherlands (Kuijvenhoven, 2006) and the Copernicus Institute for Sustainable Development and Innovation of Utrecht University (Hamelinck, 2004). The economic evaluation (Londo et al., 2008) is based on constant $€$ of 2002 and results in a net production cost (including the sales of electricity as a by-product) of $€ 0.62 / 1$ in 2010 (forest wood as feedstock, production capacity of 100,000 tons ethanol per year), $€ 0.59 / 1$ in 2020 (200,000 tons ethanol per year) and $€ 0.50 / 1$ in 2030 (400,000 tons ethanol per year), given the learning curve based on expected global production and number of plants.

\section{Key drivers of the lignocellulosic ethanol production cost}

The production cost of lignocellulosic ethanol is sensitive to key parameters such as the type, composition and farm-gate price of the feedstock, the size of the ethanol plant, the conversion efficiency, and the level of investment costs. Some of these factors are illustrated in this section, in a harmonised framework. The same framework but in a different context is described in Gnansounou et al. (2005) for the production of ethanol from sweet sorghum bagasse.

The evaluation and analysis of bioethanol production cost is performed using an own spreadsheet model developed by the authors. The technology and process model is based on and follows closely the NREL design as reported in Wooley et al. (1999a). The model calculates all material and energy balances based on specified yields at each process step. Operating costs are calculated based on material flow and energy use, coupled with available cost information. Appropriate rates are used to size the equipment, and equipment costs are calculated based on NREL information for all the steps from feedstock handling and storage to manufacture of ethanol. The power law scale factors reported by NREL are used to estimate the change in cost of each equipment item with varying feedstock composition, feed capacity, yields, etc. The model is run initially at NREL conditions to ensure that it is correct and can duplicate the results from NREL. Changes are then made on various parameters to reflect the composition of selected feedstocks, yields, and specific costs. In particular, cost index values for plant capital, chemicals and materials, and labour are adapted according to the US DOE's MYPP 2009, in order to match the present economic situation in the US $(+36 \%$ for plant cost, $+38 \%$ for chemicals and materials, $+24 \%$ for labour). Actual indices of 2007 are used in the present analysis. All the costs are expressed in US\$ of 2007. The economic model applied in the spreadsheet is based on the one in NREL's ethanol process designs (Wooley et al., 1999a; Aden et al., 2002). The levelized production cost is evaluated based on a discount rate of $10 \%$.

Four production options are analysed, based on the type (and therefore composition) of feedstock, including (1) straw, (2) eucalyptus, (3) poplar and (4) switchgrass. The composition of each feedstock is taken from the US DOE's biomass feedstock composition and property database (US DOE, 2004) and is detailed in Table 3.

Again, the process design considered in the present analysis closely follows the one described by Wooley et al. (1999a). The feedstock is first crushed into chips before pre-treatment with dilute sulphuric acid, where the hemicellulose is hydrolysed. The resulting hydrolysate is detoxified in order to remove the acid as well as the inhibitors produced along the pre-treatment. A portion of the detoxified hydrolysate is fed to a batch operation to produce cellu-

Table 3

Feedstock proximate analysis (percentage weight, wet basis).

\begin{tabular}{lllll}
\hline Components & Straw (\%) & Eucalyptus (\%) & Poplar (\%) & Switchgrass (\%) \\
\hline Moisture & 15.0 & 30.0 & 50.0 & 50.0 \\
Cellulose & 27.7 & 34.0 & 21.3 & 16.8 \\
Hemicellulose & 24.9 & 18.1 & 28.7 & 27.6 \\
Xylan & 16.3 & 8.1 & 9.5 & 11.1 \\
Arabinan & 2.0 & 0.3 & 0.4 & 1.4 \\
Mannan & 0.3 & 0.7 & 2.0 & 0.2 \\
Galactan & 0.6 & 0.7 & 0.1 & 0.5 \\
Acetate & 1.9 & 3.0 & 2.3 & 0.7 \\
Lignin & 14.3 & 19.4 & 13.8 & 9.3 \\
Ash & 8.7 & 0.6 & 0.5 & 2.9 \\
Other IS & 2.1 & 2.0 & 0.0 & 1.2 \\
Other SS & 11.0 & 1.3 & 0.0 & 6.0 \\
Total & 100.0 & 100.0 & 100.0 & 100.0 \\
\hline
\end{tabular}


lase enzymes by the fungus Trichoderma reesei. The bulk of the detoxified hydrolysate and the effluent from enzyme production are added to a reactor to release glucose from cellulose through enzymatic hydrolysis. In the same vessel and simultaneously, an organism ferments the sugars from hemicellulose plus the glucose released from cellulose to ethanol. This operation is referred to as SSCF for simultaneous saccharification and co-fermentation (of C5 and $\mathrm{C6}$ sugars). The fermented beer containing about $5 \%$ (vol.) ethanol passes onto distillation where it is concentrated to approximately 95\% ethanol in the overhead. Molecular sieves then follow to recover fuel-grade ethanol (i.e. min. 99.7\% wt. according to the European legislation). The solids, containing mostly lignin and solubles from distillation, are concentrated and burned to generate steam that can provide all of the heat and electricity for the process with some excess electricity left to export. Water is treated by anaerobic digestion and methane that results is also burned for steam generation. A schematic representation of the complete process is shown in Fig. 2.

Ethanol and possible excess electricity are the only two products according to the considered plant configuration. Other possible configurations mentioned in the preceding sections are not taken into consideration in the present illustration.

The reference ethanol production capacity is taken as 200 million litres per year. The treatment capacity varies from 1600 to 2000 tons of dry matter (t DM) per day, according to the feedstock. Specific conversion yields of the pre-hydrolysis and fermentation reactions are taken from Aden et al. (2002).

The net production cost of ethanol is divided into (1) investment costs, (2) fixed operating costs (including salaries, general overhead, insurance, taxes and maintenance), (3) variable operating costs (including purchase of consumables and sales of excess electricity), and (4) feedstock costs. Feedstock costs are separated from variable operating costs due to their large share of the net production cost.

Feedstock costs are divided into non-transport (farm-gate) and transport costs and are calculated from the data in the European REFUEL project. Transport costs are divided into loading/unloading costs (US\$0.19 per ton), fixed costs (US\$2.57 per ton) and variable costs (US\$0.10 per ton per $\mathrm{km}$ ). Biomass is supposed to be collected within a circular area surrounding the ethanol plant with an availability factor of $10 \%$. The collection radius is defined as the radius of half the collection area. Biomass yields are taken as 3.52, $12.60,5.53$ and 12.99 tons of dry matter (t DM) per hectare per year, respectively for straw (15\% water), eucalyptus (30\% water), poplar (50\% water) and switchgrass (50\% water).

Ethanol production costs as calculated by the spreadsheet model are given in Table 4. The main technical parameters including details of feedstock costs, ethanol yield, electricity production and consumption, project investment are also provided.

Feedstock costs vary from US\$53/t DM (eucalyptus) to US\$123/t DM (poplar). On a per litre basis, feedstock costs vary from US $\$ 0.18 / 1$ ethanol (eucalyptus) to US $\$ 0.42 / 1$ ethanol (switchgrass). Total project investments vary from US $\$ 280$ million (poplar) to US\$310 million (straw). Ethanol yields vary from 2901/t DM (straw) to $350 \mathrm{l} / \mathrm{t}$ DM (poplar). All feedstocks except eucalyptus lead to an excess of electricity i.e. production exceeds process requirements.

Ethanol production costs on a per litre basis are largely dominated by feedstock and investment costs, while fixed and variable operating costs play a minor role. Apart from the case of eucalyptus which appears to be a cheaper feedstock, total production costs are composed of $50-55 \%$ feedstock costs, 35-40\% investment costs and $10 \%$ variable costs. If only non-feedstock costs are taken into account, investment costs represent an average of $75 \%$. Second generation ethanol is indeed heavier on investment than first generation production pathways. Unless the selected feedstock for ethanol production turns out to be a waste in sufficient quantities at a reasonable distance from the plant, its cost on a per litre basis is far from being negligible, even though it is less than for first generation ethanol. These results show the importance of properly evaluating the availability and price of lignocellulosic feedstocks for ethanol production. The results regarding ethanol production costs on a per litre basis are illustrated in Fig. 3.

The sensitivity of the production cost with respect to parameters such as plant investment, feedstock cost, plant size and ethanol yield is now evaluated.

\subsection{Sensitivity of ethanol production cost with respect to production capacity}

The analysis is performed for the case of ethanol production from straw. Similar results are obtained with other feedstocks.

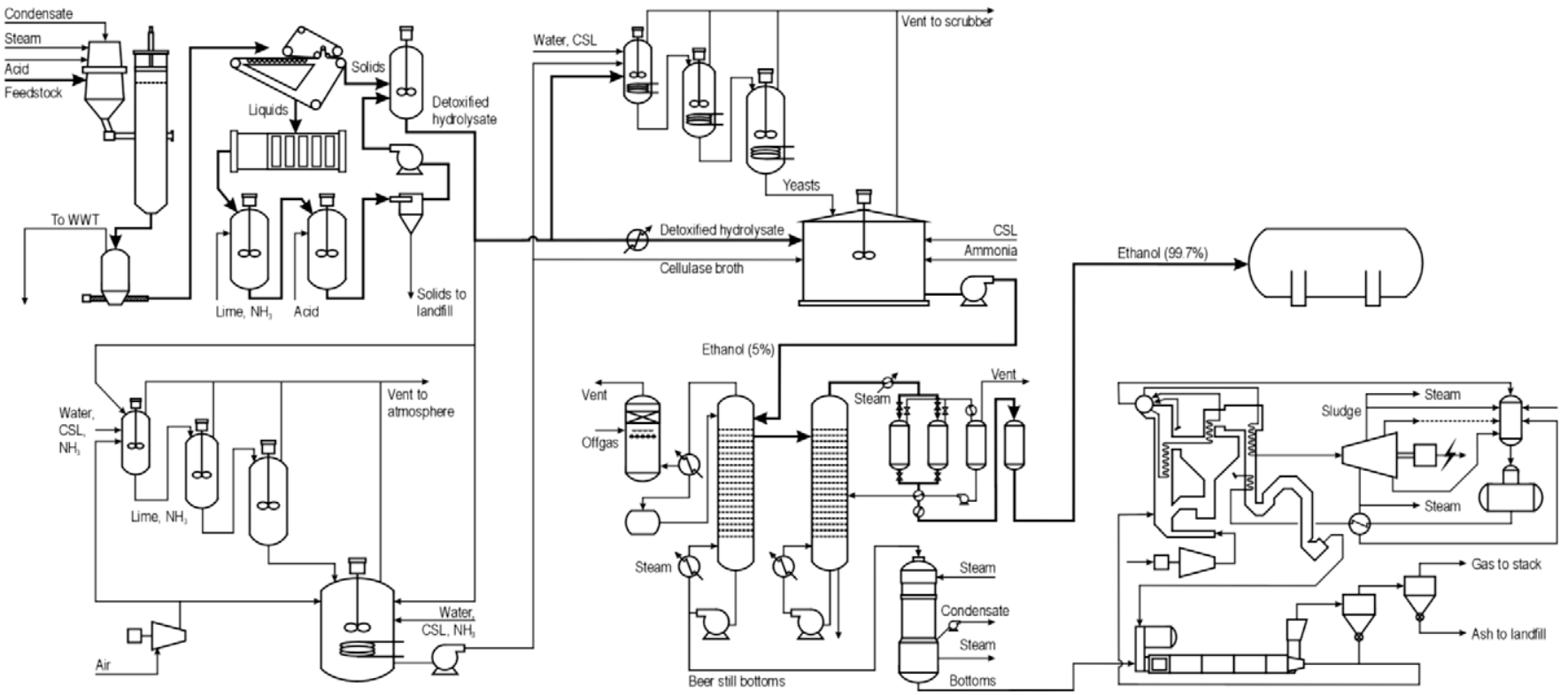

Fig. 2. Schematic diagram of the ethanol production process (adapted from NREL, 1999). 
Table 4

Ethanol production cost and production parameters as a function of feedstock.

\begin{tabular}{|c|c|c|c|c|c|}
\hline & & Straw & Eucalyptus & Poplar & Switchgrass \\
\hline \multicolumn{6}{|l|}{ General data } \\
\hline Ethanol production capacity & Ml & 200 & 200 & 200 & 200 \\
\hline Biomass treatment capacity & t DM/day & 1960 & 1680 & 1636 & 1818 \\
\hline Total project investment & Mio US\$ & 309 & 290 & 281 & 296 \\
\hline \multicolumn{6}{|l|}{ Feedstock } \\
\hline Non-transport cost & US\$/t DM & 97.30 & 52.81 & 123.33 & 118.01 \\
\hline Transport cost & US\$/t DM & 11.65 & 9.57 & 17.06 & 13.29 \\
\hline Total cost & US\$/t DM & 108.95 & 62.38 & 140.39 & 131.30 \\
\hline Yield & $\mathrm{t} \mathrm{DM} / \mathrm{ha} \mathrm{yr}$ & 3.523 & 12.600 & 5.530 & 12.990 \\
\hline Average collection radius & $\mathrm{km}$ & 55.7 & 27.3 & 40.6 & 27.9 \\
\hline Availability factor & ha/ha & $10 \%$ & $10 \%$ & $10 \%$ & $10 \%$ \\
\hline \multicolumn{6}{|l|}{ Process } \\
\hline Ethanol yield & $1 / \mathrm{t} \mathrm{DM}$ & 291.3 & 339.9 & 349.0 & 314.1 \\
\hline Total electricity produced & $\mathrm{MWh} / \mathrm{yr}$ & 54.8 & 25.9 & 26.1 & 39.6 \\
\hline Net electricity consumed & $\mathrm{MWh} / \mathrm{yr}$ & 22.4 & 31.0 & 25.3 & 21.9 \\
\hline Excess electricity & $\mathrm{MWh} / \mathrm{yr}$ & 32.3 & 0.0 & 0.8 & 17.7 \\
\hline Electricity purchased & $\mathrm{MWh} / \mathrm{yr}$ & 0.0 & 5.1 & 0.0 & 0.0 \\
\hline \multicolumn{6}{|l|}{ Production cost } \\
\hline Feedstock cost & US\$/1 & 0.37 & 0.18 & 0.40 & 0.42 \\
\hline Variable operating cost & US\$/1 & 0.02 & 0.07 & 0.05 & 0.03 \\
\hline Fixed operating cost & US\$/1 & 0.05 & 0.05 & 0.04 & 0.05 \\
\hline Investment cost & US\$/1 & 0.29 & 0.26 & 0.26 & 0.27 \\
\hline Total production cost & US\$/1 & 0.73 & 0.56 & 0.76 & 0.77 \\
\hline Total non-feedstock cost & US\$/1 & 0.36 & 0.38 & 0.36 & 0.35 \\
\hline
\end{tabular}

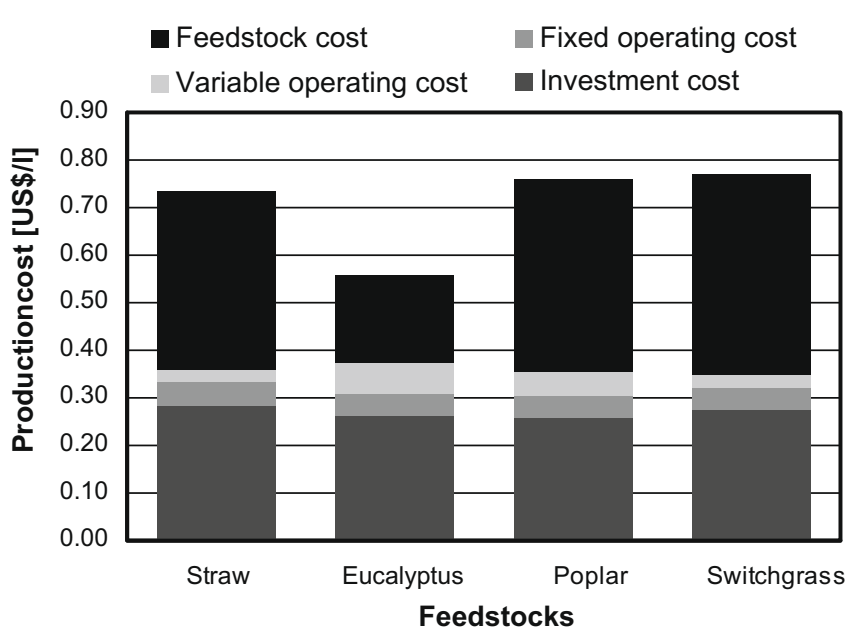

Fig. 3. Ethanol production cost as a function of feedstock.

The production cost is calculated for ethanol plants with production capacities of 50,100, 200 and 400 million litres per year $(\mathrm{Ml} / \mathrm{yr})$. The results are shown in Fig. 4.

The choice of the production capacity has an effect not only on investment costs, but also on feedstock transport costs and fixed operating costs; salaries and maintenance costs depend on the size of the plant, but not linearly. According to the results in Fig. 4, the larger the ethanol plant, the lower the production cost. It can be considered, due to the relatively low contribution of operating costs to the total production cost, that the effect of plant size on operating costs is almost negligible. The trade-off therefore is between investment costs and feedstock transport costs. On a per litre basis, the larger the ethanol plant, the lower the investment cost due to economy of scale, but the larger the feedstock transport cost. The optimal size of an ethanol plant therefore largely depends on regional conditions and on the availability of feedstock. The latter will have an effect on feedstock transport costs, but may also have some on feedstock non-transport costs depending on local conditions. In the conditions described in the present analysis, a doubling of the production capacity (from 200 to $400 \mathrm{Ml} / \mathrm{yr}$ ) results in a $10 \%$ reduction of the net production cost (from US $\$ 0.73 / 1$ to US $\$ 0.67 / 1$ ). A halving of the production capacity (from 200 to $100 \mathrm{Ml} / \mathrm{yr}$ ) results in a $15 \%$ increase of the net production cost (from US\$0.73/1 to US\$0.84/1).

The trade-off between plant size and transport distance in favour of plant size in terms of production cost may be largely different when considering the environmental impact of ethanol production. The conversion infrastructure indeed is generally hardly significant when evaluating the energy or greenhouse gas (GHG) balance of biofuel production. Transport operations, however, especially biomass transport, are far from being negligible in terms of their environmental impact. Therefore, there might also be a trade-off between environmental impact and production cost in terms of plant size, with larger plants resulting in lower production cost but larger environmental impact due to more transport.

\subsection{Sensitivity of ethanol production cost with respect to ethanol yield}

Again, the analysis is performed for the case of ethanol production from straw. The production capacity is taken as $200 \mathrm{Ml} / \mathrm{yr}$. The production cost is calculated according to four different sets of conversion efficiencies, including those of NREL's ethanol process designs (Wooley et al., 1999a; Aden et al., 2002). Two additional sets of conversion efficiencies are taken into account: one with conversion of only cellulose C6 sugars to ethanol with efficiencies as in Aden et al. (2002), referred to as "C6 only"; one corresponding to the theoretical maximum ethanol yield, referred to as "Max". The corresponding reaction-specific efficiencies are detailed in Table 5.

The corresponding ethanol yields are 189.2 1/t DM ("C6 only"), 249.7 1/t DM ("1999"), 291.3 1/t DM ("2002") and 340.4 1/t DM ("Max"). The "C6 only" scenario optimizes the production and sales of excess electricity, while the "Max" corresponds to the maximum production of ethanol. The results are shown in Fig. 5.

According to the results in Fig. 5, the higher the ethanol yield, the lower the net production cost of ethanol. Higher ethanol yields also result in a lower electricity output. Ethanol production costs 


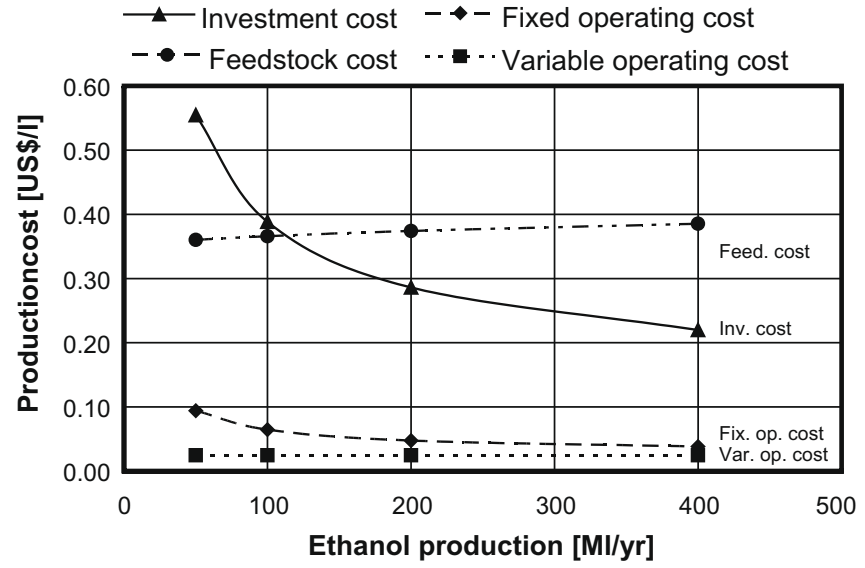

\begin{tabular}{llrrrr}
\hline Production capacity & MI/yr & $\mathbf{5 0}$ & $\mathbf{1 0 0}$ & $\mathbf{2 0 0}$ & $\mathbf{4 0 0}$ \\
\hline Variable operating cost & US\$/I & 0.02 & 0.02 & 0.02 & 0.02 \\
Fixed operating cost & US\$/I & 0.09 & 0.06 & 0.05 & 0.04 \\
Investment cost & US\$/I & 0.55 & 0.39 & 0.29 & 0.22 \\
Feedstock cost & US\$/I & 0.36 & 0.37 & 0.37 & 0.39 \\
\hline Total cost & US\$/I & $\mathbf{1 . 0 3}$ & $\mathbf{0 . 8 4}$ & $\mathbf{0 . 7 3}$ & $\mathbf{0 . 6 7}$ \\
\hline
\end{tabular}

\begin{tabular}{llrrrr}
\hline Type of feedstock & & Straw & Straw & Straw & Straw \\
Conversion efficiencies & & 2002 & 2002 & 2002 & 2002 \\
Ethanol production capacity & Ml/yr & 50 & 100 & 200 & 400 \\
Biomass treatment capacity & t DM/day & 490 & 980 & 1960 & 3920 \\
Total project investment & mio US\$ & 152 & 211 & 309 & 469 \\
\hline Feedstock data & & & & & \\
Non-transport cost & US\$/t DM & 97.30 & 97.30 & 97.30 & 97.30 \\
Transport cost & US\$/t DM & 7.65 & 9.30 & 11.65 & 14.96 \\
Total cost & US\$/t DM & 104.95 & 106.60 & 108.94 & 112.25 \\
Yield & $\mathrm{t} \mathrm{DM/ha.yr}$ & 3.523 & 3.523 & 3.523 & 3.523 \\
Average collection radius & $\mathrm{km}$ & 27.8 & 39.4 & 55.7 & 78.8 \\
Availability & ha/ha & $10 \%$ & $10 \%$ & $10 \%$ & $10 \%$ \\
\hline Process & & & & & \\
Ethanol yield & $\mathrm{l} / \mathrm{t} \mathrm{DM}$ & 291.3 & 291.3 & 291.3 & 291.3 \\
Total electricity produced & $\mathrm{MWh} / \mathrm{yr}$ & 13.7 & 27.4 & 54.8 & 109.5 \\
Net electricity consumed & $\mathrm{MWh} / \mathrm{yr}$ & 5.6 & 11.2 & 22.4 & 44.9 \\
Excess electricity & $\mathrm{MWh} / \mathrm{yr}$ & 8.1 & 16.2 & 32.3 & 64.6 \\
Electricity purchased & $\mathrm{MWh} / \mathrm{yr}$ & 0.0 & 0.0 & 0.0 & 0.0 \\
\hline
\end{tabular}

Fig. 4. Sensitivity of ethanol production cost with respect to production capacity.

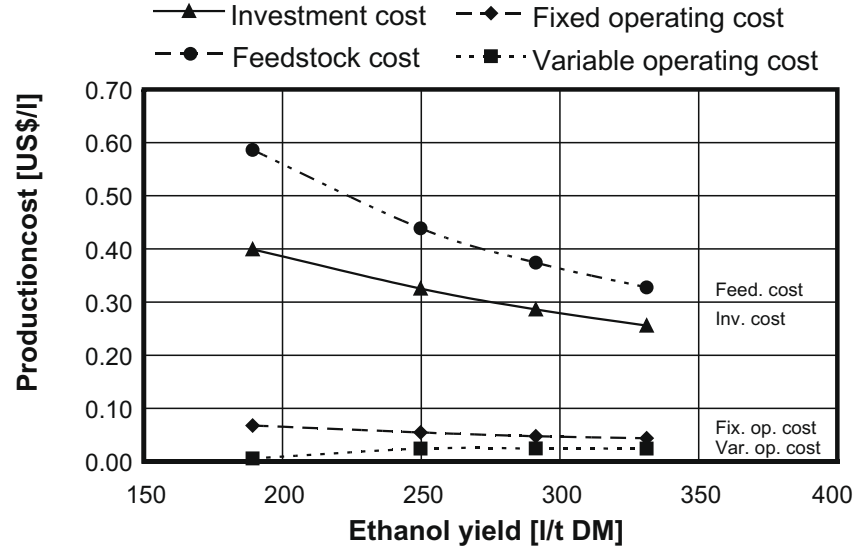

\begin{tabular}{llllll}
\hline Ethanol yield & U/t DM & 189 & $\mathbf{2 5 0}$ & $\mathbf{2 9 1}$ & $\mathbf{3 3 1}$ \\
\hline Variable operating cost & US\$/I & 0.01 & 0.02 & 0.02 & 0.02 \\
Fixed operating cost & US\$/l & 0.07 & 0.05 & 0.05 & 0.04 \\
Investment cost & US\$/I & 0.40 & 0.33 & 0.29 & 0.26 \\
Feedstock cost & US\$// & 0.59 & 0.44 & 0.37 & 0.33 \\
\hline Total cost & US\$/I & $\mathbf{1 . 0 6}$ & $\mathbf{0 . 8 4}$ & $\mathbf{0 . 7 3}$ & $\mathbf{0 . 6 5}$ \\
\hline
\end{tabular}

\begin{tabular}{llrrrr}
\hline Type of feedstock & & Straw & Straw & Straw & Straw \\
Conversion efficiencies & & C6 only & 1999 & 2002 & Max \\
Ethanol production capacity & Ml/yr & 200 & 200 & 200 & 200 \\
Biomass treatment capacity & t DM/day & 3018 & 2287 & 1960 & 1724 \\
Total project investment & mio US\$ & 429 & 351 & 309 & 276 \\
\hline Feedstock data & & & & & \\
Non-transport cost & US $/ \mathrm{t} \mathrm{DM}$ & 97.30 & 97.30 & 97.30 & 97.30 \\
Transport cost & US\$/t DM & 13.57 & 12.29 & 11.65 & 11.15 \\
Total cost & US\$/t DM & 110.87 & 109.58 & 108.94 & 108.45 \\
Yield & $\mathrm{t} \mathrm{DM/ha.yr}$ & 3.523 & 3.523 & 3.523 & 3.523 \\
Average collection radius & $\mathrm{km}$ & 69.1 & 60.2 & 55.7 & 52.2 \\
Availability & ha/ha & $10 \%$ & $10 \%$ & $10 \%$ & $10 \%$ \\
\hline Process & & & & & \\
Ethanol yield & l/t DM & 189.2 & 249.7 & 291.3 & 331.3 \\
Total electricity produced & $\mathrm{MWh} / \mathrm{yr}$ & 124.1 & 74.2 & 54.8 & 40.8 \\
Net electricity consumed & $\mathrm{MWh} / \mathrm{yr}$ & 35.5 & 28.2 & 22.4 & 18.2 \\
Excess electricity & $\mathrm{MWh} / \mathrm{yr}$ & 88.6 & 46.0 & 32.3 & 22.7 \\
Electricity purchased & $\mathrm{MWh} / \mathrm{yr}$ & 0.0 & 0.0 & 0.0 & 0.0 \\
\hline
\end{tabular}

Fig. 5. Sensitivity of ethanol production cost with respect to ethanol yield.

Table 5

Conversion rates applied according to NREL (Wooley et al., 1999a,b; Aden et al., 2002).

\begin{tabular}{|c|c|c|c|c|c|}
\hline \multirow[t]{2}{*}{ Process step } & \multirow[t]{2}{*}{ Reactions } & \multicolumn{4}{|c|}{ Conversion rates } \\
\hline & & Low (\%) & NREL 1999 (\%) & NREL 2002 (\%) & $\operatorname{Max}(\%)$ \\
\hline \multirow[t]{6}{*}{ Pre-hydrolysis } & Cellulose to glucose & 5.0 & 6.5 & 7.0 & 10.0 \\
\hline & Xylan to xylose & 70 & 75 & 90 & 100 \\
\hline & Mannan to mannose & 70 & 75 & 90 & 100 \\
\hline & Galactan to galactose & 70 & 75 & 90 & 100 \\
\hline & Arabinan to arabinose & 70 & 75 & 90 & 100 \\
\hline & Acetate to acetic acid & 100 & 100 & 100 & 100 \\
\hline \multirow{5}{*}{ Seed fermentation } & Cellulose to glucose & 20 & 20 & 20 & 20 \\
\hline & Glucose to ethanol & 80 & 85 & 90 & 95 \\
\hline & Glucose to carbon dioxide & 80 & 85 & 90 & 95 \\
\hline & Xylose to ethanol & 75 & 80 & 80 & 90 \\
\hline & Xylose to carbon dioxide & 75 & 80 & 80 & 90 \\
\hline \multirow{5}{*}{ Production fermentation } & Cellulose to glucose & 70 & 80 & 90 & 100 \\
\hline & Glucose to ethanol & 90 & 92 & 95 & 95 \\
\hline & Glucose to carbon dioxide & 90 & 92 & 95 & 95 \\
\hline & Xylose to ethanol & 80 & 85 & 85 & 93 \\
\hline & Xylose to carbon dioxide & 80 & 85 & 85 & 93 \\
\hline
\end{tabular}


vary from US\$1.06/1 ("C6 only") to US\$0.73/1 (“2002”), and could even be as low as US\$0.65/1 under the "Max" scenario. The improvement of conversion efficiencies between 1999 and 2002 ethanol process designs by NREL results in an improved ethanol yield $(+17 \%)$ and a reduced net production cost $(-13 \%)$. The net production cost is largely dependent on the price of "renewable" electricity on the local market; US $\$ 0.02 / \mathrm{kWh}$ in the present situation.

All cost components are affected by a change in ethanol yield, but at various degrees. Higher ethanol yields result in lower feedstock expenditures (less feedstock required per litre of ethanol output), but also in lower investment costs (lower treatment capacity for a given production capacity, and therefore smaller equipment and reduced investment), and lower fixed operating costs (in proportion somewhat to the investment cost).

In the "C6 only" scenario where the hemicellulose is not converted to ethanol, unconverted solids are considered to be burned together with the lignin to produce heat and electricity. Depending on the process design, however, the hemicellulose may be converted to various value-added products. What is produced out of the various components of lignocellulosic biomass has a significant effect on the economics of cellulosic ethanol production, which is likely also to depend on local conditions.

\subsection{Sensitivity of ethanol production cost with respect to feedstock non-transport cost}

Feedstock costs represent one of the most significant components of the production cost of ethanol. The sensitivity of ethanol production cost with respect to feedstock cost is analysed for various values of non-transport feedstock costs, from US\$25/t DM to US\$150/t DM. The analysis is again performed for ethanol production from straw, in a facility with a production capacity of $200 \mathrm{Ml} /$ yr. The results are shown in Fig. 6.

Given the conversion efficiencies from Aden et al. (2002), each litre of ethanol requires $3.43 \mathrm{~kg}$ DM of straw. Given the hypotheses on biomass yield i.e. $3.52 \mathrm{t} \mathrm{DM} / \mathrm{ha}$ in the case of straw and availability ( $10 \%$ in a circular area surrounding the ethanol plant), transport cost amounts to almost US\$12/t DM or US\$0.04/1 ethanol.

The changes in non-transport feedstock costs only affect the feedstock cost components. None of the other cost components is affected by such changes. In case of a freely available feedstock (i.e. the only cost is the cost of collection), the net production cost of ethanol is found to be US\$0.40/1. However, due to the required amount of feedstock, such a condition would rarely appear. It comes out from the results in Fig. 6 that total feedstock costs (including transport costs) exceed investment costs (on a per litre basis) when non-transport feedstock costs exceed US\$71/t DM. The total cost of feedstock in the present analysis (on a per litre basis) varies from US\$0.13/1 (US\$25/t DM straw) to US\$0.55/1 (US\$150/t $\mathrm{DM})$. The average cost of straw according to the REFUEL project is considered to be US\$97/t DM (excluding transport), which corresponds to US $\$ 0.33 / 1$ (or US\$0.37/1 including transport costs). Although it is often considered that the availability and low cost of feedstock is one of the main advantages of second generation biofuels, the results in the present analysis show that, feedstock may still represent the largest cost component of cellulosic ethanol net production cost, depending on local and biomass market conditions.

The expected development of bioenergy in all forms (from heating to transportation purposes) and of non-energy biomass applications is likely to modify the present notion of lignocellulosic waste. There might be situations where several facilities are in competition for a given biomass, which is likely to bring its price up. Therefore, cheap and largely available feedstock may often not be a reality, again depending on local conditions.

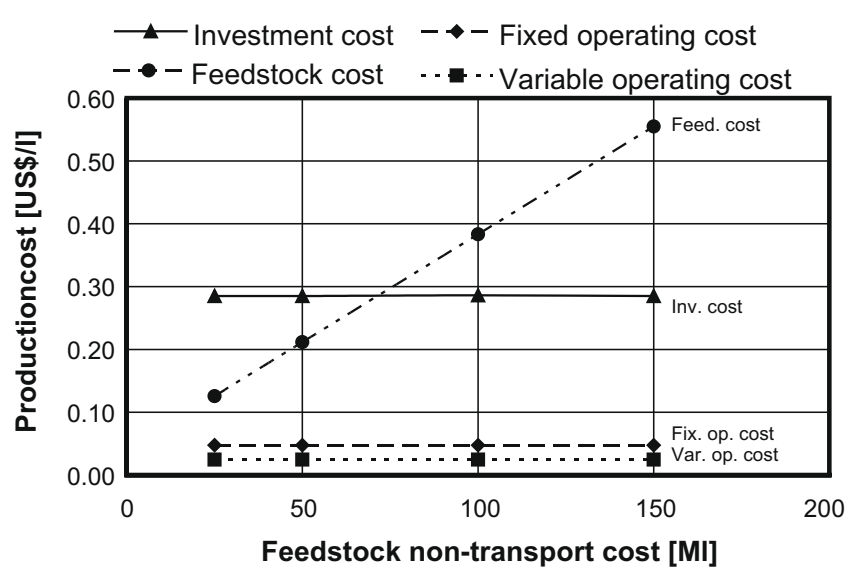

\begin{tabular}{llrrrr}
\hline Feed. non-transport cost & US\$/t DM & $\mathbf{2 5}$ & $\mathbf{5 0}$ & $\mathbf{1 0 0}$ & $\mathbf{1 5 0}$ \\
\hline Variable operating cost & US\$/ & 0.02 & 0.02 & 0.02 & 0.02 \\
Fixed operating cost & US\$/I & 0.05 & 0.05 & 0.05 & 0.05 \\
Investment cost & US\$/I & 0.29 & 0.29 & 0.29 & 0.29 \\
Feedstock cost & US\$// & 0.13 & 0.21 & 0.38 & 0.55 \\
\hline Total cost & US\$/I & $\mathbf{0 . 4 8}$ & $\mathbf{0 . 5 7}$ & $\mathbf{0 . 7 4}$ & $\mathbf{0 . 9 1}$ \\
\hline
\end{tabular}

\begin{tabular}{|c|c|c|c|c|c|}
\hline Type of feedstock & & Straw & Straw & Straw & Straw \\
\hline Conversion efficiencies & & 2002 & 2002 & 2002 & 2002 \\
\hline Ethanol production capacity & $\mathrm{Ml} / \mathrm{yr}$ & 200 & 200 & 200 & 200 \\
\hline Biomass treatment capacity & t DM/day & 1960 & 1960 & 1960 & 1960 \\
\hline Total project investment & mio US\$ & 227 & 227 & 309 & 227 \\
\hline \multicolumn{6}{|l|}{ Feedstock data } \\
\hline Non-transport cost & US\$/t DM & 25.00 & 50.00 & 100.00 & 150.00 \\
\hline Transport cost & US\$/t DM & 11.65 & 11.65 & 11.65 & 11.65 \\
\hline Total cost & US\$/t DM & 36.65 & 61.65 & 111.65 & 161.65 \\
\hline Yield & t DM/ha.yr & 3.523 & 3.523 & 3.523 & 3.523 \\
\hline Average collection radius & $\mathrm{km}$ & 55.7 & 55.7 & 55.7 & 55.7 \\
\hline Availability & ha/ha & $10 \%$ & $10 \%$ & $10 \%$ & $10 \%$ \\
\hline \multicolumn{6}{|l|}{ Process } \\
\hline Ethanol yield & I/t DM & 291.3 & 291.3 & 291.3 & 291.3 \\
\hline Total electricity produced & MWh/yr & 54.8 & 54.8 & 54.8 & 54.8 \\
\hline Net electricity consumed & $\mathrm{MWh} / \mathrm{yr}$ & 22.4 & 22.4 & 22.4 & 22.4 \\
\hline Excess electricity & $\mathrm{MWh} / \mathrm{yr}$ & 32.3 & 32.3 & 32.3 & 32.3 \\
\hline Electricity purchased & $\mathrm{MWh} / \mathrm{yr}$ & 0.0 & 0.0 & 0.0 & 0.0 \\
\hline
\end{tabular}

Fig. 6. Sensitivity of ethanol production cost with respect to feedstock nontransport cost.

\section{Cost management system}

Techno-economic evaluation of lignocellulosic bioethanol is supposed to follow one of the three types of cost management system available in the literature of strategic cost management i.e. Value Engineering (VE), Target Costing (TC) and Combined Target Costing and Value Engineering (TC\&VE). Each of these is described below with emphasis on their application to lignocellulosic bioethanol.

\subsection{Value Engineering (VE)}

Value Engineering (VE) is a set of techniques which aim at reducing the production cost of a product or service by identifying the main cost reduction opportunities, generating cost improvement alternatives and find out the best one (Ibusuki and Kaminski, 2007). In VE, each basic function in the system is specified and analysed along with the interactions. The use of VE started during World War II when the shortage of resources forced to highly value creative and least cost designs. Nowadays VE is used in order to design innovative products, increase the competitiveness and access marketplace with low industrial and economic risks. 
In the case of lignocellulosic ethanol, process design, modelling and cost analyses are included in VE (Wooley et al., 1999b). Cost reduction analyses dictate the detail level of the process design. Data collection and process flowsheeting allow a consistent design of each part of the process.

An alternative practice to VE is to only rely on designs made by external specialized engineering consultants with the risk to miss the overall consistency that requires an integration of knowledge. The complexity of techno-economic evaluation of emerging technologies such as lignocellulosics-to-ethanol requires a pluridisciplinary approach only capable as long as the development of a morphological appraisal tool is concerned. Several issues are at stake along the process chain including the suitable choice and operation options of the feedstocks, pre-treatment, enzymes production, saccharification, fermentation of most sugars, especially hexoses and pentoses, integration or not of the latter two segments, distillation, valorisation of the stillage, and energy integration. The complementarily use of process development units (PDU) and sophisticated process simulators such as ASPEN PLUS has permitted significant progress during the last decades. VE allows to perform the best available estimates and the near-term expected states i.e. next two years of the lignocellulosic ethanol pathways.

The chosen feedstocks depend mostly on the availability and cost. In the US for example, two feedstocks are mainly considered by the NREL as base cases, i.e. a hardwood (yellow poplar) and an agricultural residue (corn stover), while in a northern European forest country, as it is the case for Sweden, a softwood (spruce) is generally evaluated. There are significant differences between those three feedstocks that can impact the process design and the ethanol production cost. As an example, contrary to yellow poplar, the acetate levels in corn stover and in spruce are low, resulting in less costly detoxification step. The percentage of hexoses in spruce is also higher, thereby implying a higher potential yield in the current state of conversion efficiencies. However the most significant feedstock impact on the ethanol production cost is the feedstock cost. In that sense, assumptions made in the US earlier studies are often more optimistic than in European ones.

Although dilute acid and steam explosion are the two pre-treatment processes mostly used in integrated assessments, other processes are under study and should deserve more attention especially liquid hot water, ammonia fiber explosion (AFEX), and $\mathrm{CO}_{2}$ explosion which are more promising for meeting the following requirements: improve efficacy, reduce pre-treatment costs, decrease inhibitors and toxic matters production, and enhance flexibility of feedstocks use and end co-products valorisation. Due to these challenges, pre-treatment stage is considered as one of the most influencing stage for reducing the overall process cost.

Lignocellulosic feedstocks can be directly saccharified by acid hydrolysis. However, recycling the acid proves to be expensive. Enzymatic saccharification is then the alternative which is mostly studied in the reviewed papers. The major bottleneck of enzymatic saccharification is the cost of cellulases. Although they have been significantly reduced during the last decade, they remain high. Cellulases consist of at least three types of enzymes: endoglucanases weaken the structure of the cellulosic biomass by cutting randomly amorphous components of cellulose; exoglucanases attack the exposed ends and produce cellobiose units; and cellobiases hydrolyse the cellobiose into glucose. Trichoderma reesei, a mesophilic and filamentous fungus, is frequently used to produce cellulase complex. This organism produces abundant amounts of endoglucanases and exoglucanases but lesser cellobiases. Furthermore cellulases are inhibited by cellobiose and glucose for certain concentration levels. Cellulases can be produced by solid-state fermentation (Pandey et al., 1999) or more usually by submerged fermentation (Tolan and Foody, 1999).
Besides more used cellulase-producing fungi, cellulase-producing bacteria are being considered for their biodiversity which allows isolating strains that can survive in harsh environments and produce enzymes which are stable even in extreme conditions (Maki et al., 2009). Another option for coping with inhibition of cellulases by end-products is to simultaneously produce and ferment glucose in the so-called simultaneous saccharification and fermentation reactor (SSF). Besides potential improvement of the enzymes activity, SSF halves the number of reactors, decreases investment cost and improves the overall production cost (Wingren et al., 2003). The main bottleneck for developing SSF is to cope with the difference between optimal temperatures of saccharification and fermentation. The most challenging in this way is to integrate the four steps i.e. enzyme production, saccharification, and fermentation of hexoses and pentoses. The consolidated bio-processing CBP (Lynd et al., 2005) is the technology breakthrough that is expected for significantly reducing process costs. Direct microbial conversion DMC (Lee, 1997) is one of the representatives of this concept.

Costing within VE consists in estimating the production cost of large scale ethanol plant based on scale up of the demonstration plant, state-of-the-art technology and price quotes by process providers. Short- and medium-term costs are projected as well based on technological progress and learning curve. As an example, in the US, the state of technology (SOT) report typically proceeds with VE-based costing. While short- and near-term maturing technologies are concerned with VE-based costing, futurist ones such as CBP should be excluded as the cost information is barely based on consolidated industrial data.

\subsection{Target Costing (TC) with or without VE}

While costing within VE framework remains a standard "COST PLUS" approach, Target Costing (TC) is rather a market oriented method applied from the design stage. According to most of the production economics literature (Kato, 1993; Cooper and Slagmulder, 1997; Feil et al., 2004; Ibusuki and Kaminski, 2007), TC originates from Japan where it is commonly used since the 1960 s to manage production cost and gain competitiveness advantage. Few authors however investigate early adoption of TC in western countries. Wijewardena and de Zoysa (1999) perform a comparative analysis of cost management in Japan and Australia and find that several Australian companies apply TC as cost planning method. Dekker and Smidt (2003) survey the use of TC by Dutch firms, and Ellram (2006) investigates the TC practices in the US and highlights the more frequent implementation of TC in R\&D and supply chains contrary to assertions of previous works. Based on Ellram (1999), we derive the six-step application of TC to the design of lignocellulosic ethanol pathways (Fig. 7).

\subsubsection{Step 1: Identify desired ethanol characteristics}

The characteristics of lignocellulosic ethanol desired by the stakeholders are not only related to physical and chemical properties of the products as specified by technical standards but also such sustainability factors as environmental, social and economic performances. These characteristics depend on several types of actors: public authorities define the minimum sustainability requirements if they setup mandates and develop incentives; potential intermediate purchasers may influence the sustainability characteristics beyond the minimum requirements level; consumers may express a willingness to pay for additional value; particular uses of the product may be prioritised by the consumers which result in certain values. These grounds may evolve in the future with the evolution of societal values and public regulation. In that sense, the comparison between lignocellulosic ethanol and gasoline must not be based only on heating values. 


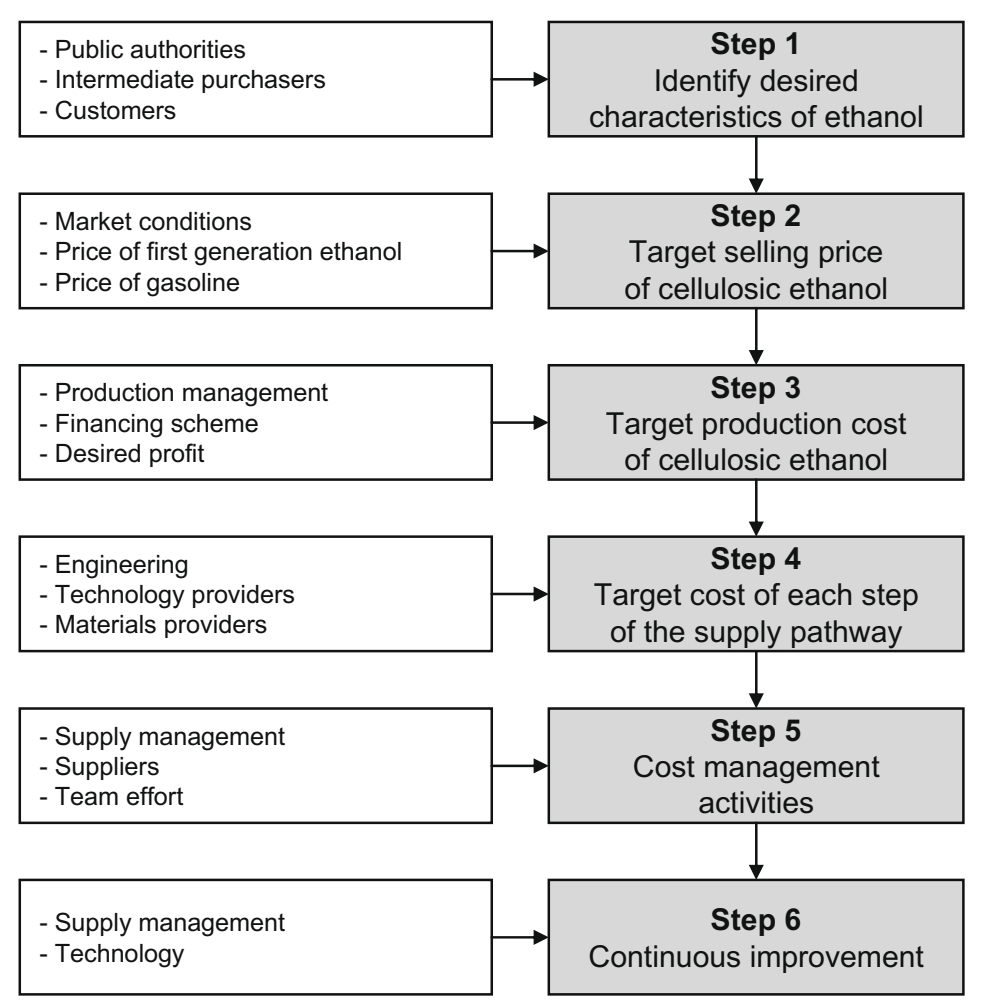

- Physical properties (technical standards)

- Chemical properties (technical standards)

- Sustainability (i.e. environmental, social, economic performance)

Fig. 7. Target Costing of lignocellulosic ethanol pathways (modified from Ellram, 1999).

\subsubsection{Step 2: Target selling price of lignocellulosic ethanol}

With respect to step 1 , the definition of the future selling price is not straightforward. A common practice is to consider as reference selling price either the market price of the first generation bioethanol or the price of gasoline. If lignocellulosic bioethanol is considered as a distinct product compared to certain first generation bioethanol types, the question whether it could be marketed as a distinct product is relevant. With the increase of the market share of ethanol its price will be more and more correlated with the price of gasoline which in turn is volatile due the demand/supply of petroleum and refined products.

\subsubsection{Step 3: Target cost of lignocellulosic ethanol}

Once the desired profit level is decided by the management, the overall allowable cost is estimated as price minus profit. The level of profit depends on the financing scheme. For techno-economic evaluation, it is often assumed a $100 \%$ equity financing and a certain discount rate that results in a maximum allowable cost given the assumed price.

\subsubsection{Step 4: Target cost of each step of the supply pathway}

Based on pieces of information gathered from engineering and potential materials and technology providers, the cost of each area is estimated. Apportioning the overall allowable cost into detailed costs of areas and sub-areas is the core of the TC approach. Each detailed cost is then a key factor for design, and material and equipment bill negotiation with the providers.

\subsubsection{Step 5: Cost management activities}

Distribution of the overall allowable cost among the areas and sub-areas in order to define target costs requires several cost management activities for targets to be robust enough. Long-term involvement of the stakeholders, particularly making the supply reliable and the suppliers faithful to the ethanol industry is one of the concerns of the cost management activities. Cost management at different areas and sub-areas in order to match the overall allowable cost is an integral part of the TC process. VE may be integrated in this step in order to conciliate cost allowance and cost targets.

\subsubsection{Step 6: Continuous improvement}

In the course of the RD\&D of lignocellulosic ethanol, information and knowledge are available with time. Development of new knowledge is liable to improve conversion efficiency and then reduce the process inputs for the same output. Efficient markets' structures of the technologies inputs and outputs, public accountability, long-term arrangements with the potential suppliers and customers, and new efficient designs are susceptible to reduce and stabilise cost and thus promote investment in the development of lignocellulosic ethanol.

\section{Current economic evaluation of lignocellulosic bioethanol: some limitations}

Current practices of techno-economic evaluation of lignocellulosic ethanol as they appear in scientific papers are rarely in full accordance with TC or VE approaches. So are practical cases of future commercial ethanol plants for which theoretical TC and VE are viewed as heavy processes. Even when applied, existing management cost systems show some drawbacks in the case of lignocellulosic ethanol where the resources are as important as the technology and values more relevant than market prices.

\subsection{Accounting for the competition between different uses of resources}

Lignocellulosic ethanol is often treated as a product of an integrated system from feedstock production to the use of the produced ethanol. Therefore, the technical aspects of the supply chain are prioritised compared to the actors along the pathway. 
That way of assessment neglects the potential competition for resources. Complementarily to VE, research on Value Resources should be undertaken in order to identify the main uses which will compete with lignocellulosic ethanol for resources and how their markets would develop.

\subsection{The value of lignocellulosic resources}

In the medium- to long-term, lignocellulosic resources can be used for energy production but also for chemicals and materials. Competition for resources is concerned with various conversion technologies including both energy and non-energy uses. Using MARKAL, Gielien et al. (2001) study the optimal assessment of biomass uses in Western Europe for reducing greenhouse gas, by comparing energy production with materials applications. They conclude that the main substitution to fossil feedstocks will occur in transportation fuels, petrochemicals and electricity generation. Although this approach mainly results in global scenarios which depend on the specifications of the objective function and constraints, competition between biomass applications will determine the delivery cost of biomass feedstocks. In a biomass-constrainedcase, facing several sales opportunities with different levels of willingness to pay, lignocellulosic feedstock producers will sell according to the expected maximum benefit based on opportunity cost. Thus, for a particular use, say lignocellulosic ethanol, the biomass procurement cost will not depend only on the cost of biomass activities but also on the comparative willingness to pay by biomass purchase competitors.

\subsection{The value of lignocellulosic ethanol and co-products}

In the US biomass programme, the value of lignocellulosic ethanol is estimated as $65 \%$ of gasoline market price. Such modelling choice is acceptable as long as bioethanol is supposed to be used as pure ethanol or in a high blend rate with gasoline and providing that such characteristics as GHG emission reduction, renewability, absence of competition with food and feed and lack of direct and indirect land-use impacts are not taken into account neither by the market nor by the public authorities. Full awareness of those characteristics by the customers implies a higher willingness to pay for sustainable lignocellulosic ethanol compared to another less sustainable ethanol. Public authorities can also use specific policy instruments such as feed-in tariff in order to stabilise the reference value of sustainable lignocellulosic ethanol and foster the investments. The issue of lignocellulosic ethanol value can be generalised to that of co-products when established fossil-based markets exist. High value-added co-products contribute to the competitiveness of bioethanol.

\subsection{The value of intermediate products such as monosaccharides}

Depending on existing markets, the value of intermediate products such as monosaccharides can be estimated based on the willingness to pay for various potential alternative products. That value is termed shadow price of intermediate products (Gnansounou et al., 2005). Estimation of the shadow prices allow evaluating the producer's willingness to sell lignocellulosic ethanol and his willingness to pay for feedstock.

\subsection{Economic evaluation based on the value chain}

Sustainable lignocellulosic ethanol is a specific product, the value of which should be estimated adequately. Given the non-integration of feedstock delivery, conversion to ethanol, distribution and use segments, the supply chain must be evaluated using a value-based approach. Current market price projections cannot suit- ably consider the distinctive characteristics of sustainable lignocellulosic ethanol. Practical application of a value-based approach, however, needs to consider the specific environment of the ethanol plant.

\section{Conclusion}

While demonstration activities on cellulosic bioethanol in North America (i.e. US and Canada) are concerned with both thermochemical and biochemical pathways, cellulosic bioethanol in Europe is mostly limited to the biochemical route. Demonstration projects in Europe include those of Abengoa (Spain), BioGasol (Denmark), Inbicon (Denmark), M\&G/Chemtex (Italy), Procethol 2G/Futurol (France) and SEKAB (Sweden). Other companies such as Novozymes, Danisco or Syngenta are also supporting major efforts to develop cellulosic ethanol. Demonstration cellulosic bioethanol projects in the US and Canada are even more numerous and varied. Most of the major actors have opted for the biochemical pathway, with either enzymatic hydrolysis (e.g. Abengoa, Inbicon, KL Energy, Mascoma, POET, QTeros, Verenium) or acid hydrolysis (e.g. BlueFire Ethanol). Thermochemical projects include those of Enerkem in Canada, Range Fuels and Coskata in the US. Although cellulosic ethanol efforts are still in the research phase in other countries, significant work is underway (e.g. Praj Industries and Mission New Energy in India, Petrobras in Brazil). A notable R\&D effort is also underway in Australia.

The review undertaken in this paper raises the following issues and findings: the contribution of biomass cost to the overall production cost of lignocellulosic bioethanol proves to be one of the most significant; the standard production cost estimation should be replaced by an approach which makes use of Value Engineering, Value Resource and Target Costing; due to the complexity of the techno-economic evaluation of lignocellulosic ethanol, the perceived risks by private investors will be high. Strategies to decrease these risks include promoting such projects as integration of second generation with first generation bioethanol and thus use existing residues and share equipments. Sugarcane bagasse is particularly concerned with such a strategy. Lignocellulosic-biorefineries that aim at decreasing the production cost of bioethanol will be attractive only if the perceived risks by the investors are affordable. Low risk profile biorefineries with stable product markets would be preferred to complex schemes with a high diversity of co-products whose uncertainty would make profitability highly risky.

\section{References}

Aden, A., 2008. Biochemical Production of Ethanol from Corn Stover: 2007 State of Technology Model. National Renewable Energy Laboratory (NREL), NREL Report TP-510-43205.

Aden, A., Foust, T., 2009. Technoeconomic analysis of the dilute sulfuric acid and enzymatic hydrolysis process for the conversion of corn stover to ethanol. Cellulose 16 (4), 535-545.

Aden, A., Ruth, M., Ibsen, K., Jechura, J., Neeves, K., Sheehan, J., Wallace, B. Montague, L., Slayton, A., Lukas, J., 2002. Lignocellulosic Biomass to Ethanol Process Design and Economics Utilizing Co-current Dilute Acid Prehydrolysis and Enzymatic Hydrolysis for Corn Stover. National Renewable Energy Laboratory (NREL), NREL Report TP-510-32438.

Badger Engineers, Inc., 1987. Economic Feasibility of an Acid-Hydrolysis-based Ethanol Plant. Subcontract Report SERI-STR-231-3142, Prepared under Subcontract ZX-3-03096-2. Badger Engineers, Inc., Cambridge, MA.

Chem Systems, Inc., 1987. Economic Feasibility Study of an Enzymatic Hydrolysisbased Ethanol Plant with Prehydrolysis Pretreatment. Subcontract Report SERISTR-231-3135, Prepared under Subcontract XX-3-03097-1. Chem Systems, Inc. Tarrytown, NY

Cooper, R., Slagmulder, R., 1997. Target Costing and Value Engineering. Productivity Press, New York, NY, USA.

Dekker, H., Smidt, P., 2003. A survey of the adoption and use of target costing in Dutch firms. International Journal of Production Economics 84 (3), 293-305.

EIA, 2009. Annual Energy Outlook 2009. Energy Information Administration, Office of Integrated Analysis and Forecasting. US Department of Energy, Washington, USA. 
Ellram, L.M., 1999. The Role of Supply Management in Target Costing. Center for Advanced Purchasing Studies, Tempe, AZ.

Ellram, L.M., 2006. The implementation of target costing in the United States: theory versus practice. The Journal of Supply Chain Management. Winter, 13-26.

Feil, P., Yook, K.-H., Kim, I.-W., 2004. Japanese target costing: a historical perspective. International Journal of Strategic Cost Management, Spring, 10-19.

Galbe, M., Sassner, P., Wingren, A., Zacchi, G., 2007. Process engineering economics of bioethanol production. Advances in Biochemical Engineering/Biotechnology 108, 303-327.

Gielien, D.J., de Feber, M.A.P.C., Bos, A.J.M., Gerlagh, T., 2001. Biomass for energy or materials? A Western European systems engineering perspective. Energy Policy 29 (4), 291-302.

Gnansounou, E., Dauriat, A., Wyman, C.E., 2005. Refining sweet sorghum to ethanol and sugar: economic trade-offs in the context of North China. Bioresource Technology 96 (9), 985-1002.

Hamelinck, C.N., 2004. Outlook for Advanced Biofuels. Ph.D. Thesis, Department of Science, Technology and Society and the Copernicus Institute for Sustainable Development and Innovation of Utrecht University.

Humbird, D., Aden, A., 2009. Biochemical Production of Ethanol from Corn Stover: 2008 State of Technology Model. National Renewable Energy Laboratory (NREL), NREL Report TP-510-46214.

Ibusuki, U., Kaminski, P.C., 2007. Product development process with focus on value engineering and target-costing: a case study in an automotive company. International Journal of Production Economics 105 (2), 459-474.

Kato, Y., 1993. Target costing support system: lessons from leading Japanese companies. Management Accounting Research 4, 33-47.

Kuijvenhoven, J., 2006. Process design for an integrated lignocellulose to bioethanol production plant. Presentation at Netherlands Process Technology Symposium, October 25, 2006.

Lee, J., 1997. Biological conversion of lignocellulosic biomass to ethanol. Journal of Biotechnology 56 (1), 1-24

Londo, H.M., Lensink, S.M., Deurwaarder, E.P., Wakker, A., de Wit, M.P., Junginger, H.M., Könighofer, K., Jungmeier, G., 2008. Biofuels Development in the EU27+ until 2030: Full-chain Cost Assessment and Implications of Policy Options. REFUEL Project, WP4 Final Report.

Lynd, L.R., van Zil, W.H., McBride, J.E., Laser, M., 2005. Consolidated bioprocessing of cellulosic biomass: an update. Current Opinion in Biotechnology 16 (5), 577583.

Maki, M., Leung, K.T., Qin, W., 2009. The prospects of cellulase-producing bacteria for bioconversion of lignocellulosic biomass. International Journal of Biological Sciences 5, 500-516.
Pandey, A., Selvakumar, P., Soccol, C.R., Nigam, P., 1999. Solid-state fermentation for the production of industrial enzymes. Current Science 77, 149-152.

Phillips, S., Aden, A., Jechura, J., Dayton, D., Eggeman, T., 2007. Thermochemical Ethanol via Indirect Gasification and Mixed Alcohol Synthesis of Lignocellulosic Biomass. National Renewable Energy Laboratory (NREL), Technical Report NREL/TP-510-41168.

Sassners, P., Galbe, M., Zacchi, G., 2008. Techno-economic evaluation of bioethanol production from three different lignocellulosic materials. Biomass and Bioenergy 32 (5), 422-430.

Stone \& Webster Engineering, Corp., Boston, MA, 1987. Economic Feasibility of an Enzyme-based Ethanol Plant. Subcontract Report SERI-STR-231-3138, Prepared under Subcontract ZX-3-03097-1.

Tolan, J.S., Foody, B., 1999. Cellulase from submerged fermentation. Advances in Biochemical Engineering/Biotechnology 65, 41-67.

US DOE, 2004. Biomass Feedstock Composition and Property Database. Biomass Program, Energy Efficiency and Renewable Energy (EERE), US Department of Energy (DOE) (accessed 04.10.09.).

US DOE, 2005. Multi-Year Program Plan 2007-2012. Biomass and Biorefinery System R\&D. Biomass Program, Energy Efficiency and Renewable Energy, US Department of Energy.

US DOE, 2007. Biomass Multi-Year Program Plan. Office of the Biomass Program, Energy Efficiency and Renewable Energy, US Department of Energy.

US DOE, 2009. Biomass Multi-Year Program Plan (MYPP). Office of the Biomass Program, Energy Efficiency and Renewable Energy, US Department of Energy.

Wijewardena, H., de Zoysa, A., 1999. A comparative analysis of management accounting practices in Australia and Japan: an empirical investigation. International Journal of Accounting 34 (1), 49-70.

Wingren, A., Galbe, M., Zacchi, G., 2003. Techno-economic evaluation of producing ethanol from softwood: Comparision of SSF and SHF and identification of bottlenecks. Biotechnology Progress 19, 1109-1117.

Wingren, A., Galbe, M., Zacchi, G., 2008. Energy considerations for a SSF-based softwood ethanol plant. Bioresource Technology 99 (7), 2121-2131.

Wooley, R., Ruth, M., Sheehan, J., Ibsen, K., Majdeski, H., Galvez, A., 1999a. Lignocellulosic Biomass to Ethanol Process Design and Economics Utilizing Cocurrent Dilute Acid Prehydrolysis and Enzymatic Hydrolysis: Current and Futuristic Scenarios. National Renewable Energy Laboratory (NREL), NREL Report TP580-26157.

Wooley, R., Ruth, M., Glassner, D., Sheehan, J., 1999b. Process design and costing of bioethanol technology: a tool for determining the status and direction of research and development. Biotechnology Progress 15, 794-803. 